\title{
Information and Communication Technology and the Learning of English Phonetics in Selected Secondary Schools in Nigeria: A Case Study
}

\author{
Ugboja Anthony ${ }^{1}$ \\ ${ }^{1}$ Department of Curriculum Studies and Educational Technology, University of Port Harcourt, Rivers state, Nigeria \\ Correspondence: Ugboja Anthony, Department of Curriculum Studies and Educational Technology, University of Port \\ Harcourt, Rivers state, Nigeria
}

Received: January 13, 2017

Accepted: January 26, 2017

Online Published: November 8, 2017

doi:10.5430/elr.v6n4p13

URL: http://dx.doi.org/10.5430/elr.v6n4p13

\begin{abstract}
The study investigated the Information and Communication Technology and learning of English phonetics in selected senior secondary schools in Rivers State. The study employed a descriptive survey design. A sample of ten (10) senior secondary schools was selected from Ogba/Egbema/Ndoni Local Government Area of Rivers State. 15 students were randomly selected from the 10 schools which came to a total of (150) students based on the objectives of the study five research questions were formulated four hypotheses were tested at 0.05 level of significance. The data collected was analyzed using simple descriptive methods of mean and standard deviation (SD) to answer the five research questions. Chi-Square(x2) and t-test were used to test the hypothesis at 0.05 level of significance. The results of the research revealed that there are low availabilities of ICT in Ogba/Egbema/Ndoni Local Government Area of Rivers State. The study also revealed that teachers of oral English rarely possess the skills to use the ICT facilities to teach oral English in the public and private secondary schools in Ogba/Egbema/Ndoni Local Government Area of Rivers State. The urban areas are more exposed to the use of ICT than their mates in the rural area. Students in the rural area and their mates in the urban area have similar problems in the leaning of phonetics. Based on the results it was recommended that the use of ICT to teach oral English should be encouraged in senior secondary schools. The recommendations, suggestions for further studies and contribution to knowledge were made.
\end{abstract}

Keywords: Information and Communication Technology, Learning, English language and Phonetics.

\section{Introduction}

The rapid change in our world today has brought so much innovation in communication. The innovation of technological advancement in the $21^{\text {st }}$ century; has become inevitable in our educational system. It has a great impact in diverse ways which have successfully led to the diffusion of technological advancement this era of digital technology is regarded as the force that has changed many aspects of human life.

This innovation of ICT will improve the teaching and learning of phonetics. There is no doubt that the integration of ICT into the learning of phonetics will help the students to develop creativity and problem solving ability. The introduction of ICT would make learning easy the learners; it also serves as an effective instructional material for teachers of oral English. The advent of Information and Communication Technology in educational related activities has brought about collaboration between teachers and learners as well as among the researchers in many ways to achieve good results.in this regards Yunus (2007) sees ICT learning tools used in L2 class as a wonderful instructional material that can be used to present information in different ways, in the form of pictures, text, tables graphs as well as multimedia which makes class more lively and real.

The researcher is motivated to investigate into the use of ICT in the teaching of oral English because his experience during his years of teaching oral English showed that both teachers and learners are faced with the challenges of pronunciation of English language, looking at the status of English language in Nigeria, that is as language of communication, commerce and industry, as a language politics and what have you. This aspect of English language cannot be overlooked since effective communication is a strong background in language learning. It is observed that using ICT as instructional aids in the classroom brightens up class activities and the students' mind this makes the lessons more interactive, interesting, fast and efficient. Grabe and Grabe (2005 page 15) comment on the significance of ICT as follows 
This new innovation of ICT can perform different functions the classroom; it helps the learners to be more relaxed and confident to learn many topics and perform various tasks by applying the technology rather than be directed by the technology.

It is interesting to also know that this new innovation can help students to learn spelling speech sound and pronunciation at their own convenience as interactive activities. That is why it is crucial to capture the interest of the learners so that they can be eager and ready to handle the learning tools for a change in both the learning system and for individual academic and social expansion. These roles of ICT in teaching and learning processes including speech sounds pronunciation and spoken English are imperative, it make earning active, authentic, interesting what to this aim the national policy on education (2014) edition advocates the introduction of ICT in teaching and learning in the Nigeria secondary schools. This urgent need for Information and Communication Technology in our schools comes as a result of technological advancement in our modern world.

The problems of pronunciation will be resolved with the integration of ICT into language learning. Osagie (2008) suggest that very little regard is accorded to the primacy of spoken language". This means that the importance of spoken language is overlooked, and since language and sound cannot be separated, it becomes very crucial to the L2 learners to lay more emphasis on the sound of English language since English is our official language and lingua-franca there is therefore a serious need to look into it because learning a language is all about speaking it, not just speaking it but speaking it with competence to make communication meaningful.

According to Zhoa (2003) the integration of ICT into the learning of language can be effective in every aspect of language learning. It helps to improve performance in communications and bring relevant feedback to learners Mynard (2007), has revealed that; the integration of technology in education was proved to be effective in various aspects, including the use of internet, multimedia learning and web-based learning.

Nevertheless, the latest ICT has been introduced to facilitate the study of speech sound, pronunciation as well as spoken English. The relevance of this study therefore, is to find out if the learners of oral English in Ogba/ Egbema/ Ndoni Local Government Area (ONELGA) secondary schools in Rivers state can take advantage of this $21^{\text {st }}$ century innovation.

Below are the intended aims objectives for the study: To find out the availability of ICT facilities for teaching oral English in public and private secondary schools in ONELGA.

- To find out if the teachers of oral English possess the skills to use the ICT facilities to teach oral English in public and private secondary schools in ONELGA.

- To find out the problems encountered by the students in both public and private secondary schools in learning oral English in ONELGA.

- To find out the availability of ICT materials in public and private secondary schools in both rural and urban area of ONELGA.

Below are reach questions that are used to guide the reach work.

\subsection{Research Questions}

- To what extent are ICT facilities available for teaching oral English in public and private secondary schools in ONELGA?

- To what extent do the teachers of oral English possess the skills to use the ICT facilities to teach oral English in the public and private secondary schools in ONELGA?

- What are the problems encountered by students in public and private secondary schools regarding their learning of oral English in ONELGA?

- To what extent are ICT facilities available in rural and urban area of ONELGA?

The hypotheses below were tested at 0.05 level of significant.

\subsection{Research Hypotheses}

- There is no significant difference in the availabilities of ICT facilities for teaching oral English in public and private secondary schools in ONELGA.

- There is no significant difference among teachers in government and private secondary schools regarding the skills they possess in the use of ICT facilities to teach oral English in ONELGA.

- There is no significant difference between the students in private and public secondary schools regarding the 
problems they encountered in the learning of phonetics in ONELGA

- There is no significant difference between the availability of ICT facilities in both rural and urban area.

\section{Theoretical Framework}

\section{1) Computer-mediated communication $(\mathrm{CMC})$ :}

The theoretical framework this research has adopted is the computer mediated communication theory. This research is based on the version proposed by Herb, T. (2000). The computer mediated communication (CMC) is any human communication or interactions that make use of double electronic devices. (CMC) originally it refers to all human utterances that occur through computer-mediated channels. Some of these channels are: e-mail, online forums, instant messaging, text-based interaction etc. In this era of technological advancement, it has been applied into the teaching and learning in order to meet he $21^{\text {st }}$ centuries innovations.

The integration of communication technology into education started in the mid 80's. This technological advancement was introduced by Hiltz (1988), and it was made popular by the mid-90, using the world-wide web (www), e-mail and forums. The two major online tools are: the first online learning is based on computer based training (CBT) It is also be referred to as computer based learning (CBL). This early stage basically focused on the interaction between the students and computer drills, coupled with tutorials on the one hand, the micro worlds and simulation on the other hand. Paradigm has changed to what is generally known as computer mediated communication (CMC), The mode of interactions today has changed from what it used to be. The difference here is that, CBT and CBL, are referred to as individualized learning while CMC incorporates teacher /tutor facilitation which involves he arrangement of flexible learning activities. Apart from that, this new innovation of ICT has provided education with new instructional materials which serve as a tool that can facilitate learning to perform task. The teacher even curriculum planners take advantage of this new innovation. The role of computer mediated communication is significant in full-time distance teaching and learning. This innovation of ICT has given us more control over information, It an help both the teacher and learner to focus on more complex tasks, using the computer as a major instructional tools.

\section{Literature Review}

Graham (2011) reveals that the application of Information and Communication Technology on language teaching and learning has made the lesson to be students oriented and authentic.

It has brought a better and a new way of learning.

Similarly krashen (2007) states that the use of computer makes it easy for students to surf the internet and read what lies in their interests. He posits that this brings about higher levels of literacy among students. He suggests that it will result in higher levels of literacy. Hoven (1999) claim that computers create enabling environments for learners to study at their own pace. Supporting this view, Mynard (2007) agrees that learners' autonomy is potentially facilitated by computers as students become efficient in deciding how to study with computers. However, there is still a need for instructors to help learners in understanding how a digital tool like computers can benefit their overall learning.

Burnett and Myers (2007) focused on the English language and how it can be taught using ICT. The present study however differs because it focused mainly on the availability and usage of ICT to improve the learning of phonetics in ONELGA secondary schools.

\section{Methodology}

A descriptive survey design was used to carry out the study.

There are total number of twenty (20) government approved secondary schools and nine (9) private secondary school with total number of four thousand, five hundred and twenty four (4524) ss one students with all the ICT facilities which serves as the population for the study. A sample of ten (10) senior secondary schools was selected from ONELGA. A simple random sampling technique was used to select fifteen (15) students from each school which give us a total of (150) student.

Questionnaires and observations checklist was used as research instruments for the study.

\section{Data Analysis of Research Questions}

Research Question 1: To what extent are ICT facilities available for teaching oral English in public and private secondary schools in ONELGA? 
Table 1. Observation Checklist on Availability of ICT Facilities in Public and Private Secondary Schools in ONELGA

\begin{tabular}{|c|c|c|c|c|c|c|c|c|c|}
\hline \multirow[t]{3}{*}{$\mathbf{S} / \mathbf{N}$} & \multirow[t]{3}{*}{ Items } & \multicolumn{4}{|c|}{ Public Secondary Schools (90) } & \multicolumn{4}{|c|}{ Private Secondary Schools (60) } \\
\hline & & \multicolumn{2}{|c|}{ Available } & \multicolumn{2}{|c|}{ Not Available } & \multicolumn{2}{|c|}{ Available } & \multicolumn{2}{|c|}{ Not Available } \\
\hline & & $\mathbf{F}$ & $\%$ & $\mathbf{F}$ & $\%$ & $\mathbf{F}$ & $\%$ & $\mathbf{F}$ & $\%$ \\
\hline 1. & Computer & 20 & $13.3 \%$ & 70 & $46.7 \%$ & 50 & $33.3 \%$ & 10 & $6.7 \%$ \\
\hline 2. & Television & 3 & $2.0 \%$ & 87 & $58.0 \%$ & 40 & $26.7 \%$ & 20 & $13.3 \%$ \\
\hline 3. & Voice recorded & 2 & $1.3 \%$ & 88 & $58.7 \%$ & 30 & $20.0 \%$ & 30 & $20.0 \%$ \\
\hline 4. & Smart board & 10 & $6.7 \%$ & 80 & $53.3 \%$ & 40 & $26.7 \%$ & 20 & $13.3 \%$ \\
\hline 5. & Laptops & 23 & $15.3 \%$ & 67 & $44.7 \%$ & 45 & $30.0 \%$ & 15 & $10.0 \%$ \\
\hline 6. & Android phones & 35 & $23.3 \%$ & 55 & $36.7 \%$ & 50 & $33.3 \%$ & 10 & $6.7 \%$ \\
\hline 7. & CD-ROMS & 19 & $12.7 \%$ & 71 & $47.3 \%$ & 45 & $30.0 \%$ & 15 & $10.0 \%$ \\
\hline 8. & $\begin{array}{l}\text { Interactive } \\
\text { whiteboard }\end{array}$ & 2 & $1.3 \%$ & 88 & $58.7 \%$ & 32 & $21.3 \%$ & 28 & $18.7 \%$ \\
\hline 9. & Digital cameras & 5 & $3.3 \%$ & 85 & $56.7 \%$ & 21 & $14.0 \%$ & 39 & $26.0 \%$ \\
\hline 10. & Programmable toys & 0 & $0.0 \%$ & 90 & $60.0 \%$ & 15 & $10.0 \%$ & 45 & $30.0 \%$ \\
\hline \multirow[t]{2}{*}{11.} & Projectors & 4 & $2.7 \%$ & 86 & $57.3 \%$ & 40 & $26.7 \%$ & 20 & $13.3 \%$ \\
\hline & Average (\%) & 123 & $7.5 \%$ & 867 & $52.5 \%$ & 408 & $24.7 \%$ & 252 & $15.3 \%$ \\
\hline
\end{tabular}

In table one, $\mathrm{F}$ stands for frequency. That is, the number of times a particular item appears in the table. The table also shows that $13.3 \%$ respondents from public schools had access to computers while $46.7 \%$ did not. In the private schools $33.3 \%$ had access to computers while $6.7 \%$ did not. The percentages of the availability of various ICT facilities on the checklist in the assessed public schools ranged between $0 \%$ and $23.3 \%$ while the percentages of the unavailability of the ICT facilities ranged between $44.7 \%$ and $60.0 \%$. In the private schools, it ranged between $10 \%$ and $33.3 \%$. However, on average, $7.5 \%$ from public schools had accesso ICT facilities listed on the checklist while $52.5 \%$ did not in the private schools, $24.7 \%$ had access to ICT facilities listed on the checklist while $15.3 \%$ did not his implies that the availability of ICT facilities in public secondary schools in ONELGA was low at the time of conducting this research.

Research Question 2: To what extent do the teachers of oral English possess the skills to use the ICT facilities to teach oral English in the public and private secondary schools in ONELGA? 
Table 2. The extent teachers of oral English possess the skills to use the ICT facilities to teach oral English in the public and private secondary schools in ONELGA.

\begin{tabular}{|c|c|c|c|c|c|c|c|c|c|c|}
\hline \multirow[t]{2}{*}{$\mathrm{S} / \mathrm{N}$} & \multirow[t]{2}{*}{ Items } & & \multicolumn{4}{|c|}{ Schools } & \multirow{2}{*}{$\begin{array}{l}\text { Mean } \\
\mathrm{xx} / 2\end{array}$} & \multirow[t]{2}{*}{ set } & \multirow[t]{2}{*}{ SD } & \multirow[t]{2}{*}{ Decision } \\
\hline & & & $\begin{array}{l}\text { Public } \\
(\mathrm{N}=90)\end{array}$ & $\bar{x} \bar{x}$ & $\begin{array}{l}\text { Private } \\
(\mathrm{N}=60)\end{array}$ & $\bar{x} \bar{x}$ & & & & \\
\hline 1. & $\begin{array}{l}\text { We use power poir } \\
\text { presentation to lear } \\
\text { phonetics in our school }\end{array}$ & & 1.67 & & 3.62 & & 2.45 & & 1.41 & Rejected \\
\hline 2. & $\begin{array}{l}\text { All the teachers possess th } \\
\text { skills to use the IC' } \\
\text { facilitates to teach ord } \\
\text { English. }\end{array}$ & & 2.47 & & 3.42 & & 2.85 & & 1.54 & Accepted \\
\hline 3 & $\begin{array}{l}\text { We use television an } \\
\text { CDROM to learn phonetic } \\
\text { in our school. }\end{array}$ & & 1.56 & & 3.45 & & 2.31 & & 1.39 & Rejected \\
\hline 4. & $\begin{array}{l}\text { All teacher uses voic } \\
\text { recorder to teach sound } \mathrm{i} \\
\text { our school. }\end{array}$ & & 1.82 & & 3.50 & & 2.49 & & 1.50 & Rejected \\
\hline 5. & $\begin{array}{l}\text { Smart board is always } \\
\text { used to practice sound in } \\
\text { our school. }\end{array}$ & 1.72 & & 3.15 & & 2.29 & & 1.37 & & Rejected \\
\hline 6. & $\begin{array}{l}\text { Laptop and android phone } \\
\text { is always used to practice } \\
\text { phonetics in our school. }\end{array}$ & 2.36 & & 2.92 & & 2.58 & & 1.47 & & Accepted \\
\hline 7. & $\begin{array}{l}\text { All teachers use interactive } \\
\text { whiteboard to teach } \\
\text { phonetics in our schools. }\end{array}$ & 2.10 & & 2.67 & & 2.33 & & 1.41 & & Rejected \\
\hline 8. & $\begin{array}{l}\text { All teachers uses digital } \\
\text { camera to teach phonetics. }\end{array}$ & 1.73 & & 2.52 & & 2.05 & & 1.25 & & Rejected \\
\hline 9. & $\begin{array}{l}\text { All teachers of oral } \\
\text { English are not computer } \\
\text { literate. }\end{array}$ & 3.22 & & 2.58 & & 2.97 & & 1.45 & & Accepted \\
\hline & Aggregate Mean & & & & & 2.48 & & 1.42 & & \\
\hline
\end{tabular}

Table two: showed that some students rarely used power point presentation to learn phonetics in their school or public school students, while the mean score $(\bar{x} \bar{X})=3.62$, for private school students illustrated that they used power point presentation to learn phonetics in their school. The average mean score 2.45 was rejected. Secondly, the teachers seldom possessed the skills to use the ICT facilities to teach oral English in public schools while the mean scores $\left({ }^{\bar{x}} \bar{x}\right.$ ) $=3.42$ private schools showed that teachers often possessed he skills to use ICT facilities. The average mean score 2.85 was accepted. Thirdly, television and CDROMs are not frequently used in public schools to learn phonetics while the mean score is $\left({ }^{\bar{x}} \bar{x}\right)=3.45$, for private schools. The average means score $\left({ }^{\bar{x}} \bar{x}\right)=2.31$ was rejected. However, item 4-8 were rarely used by public school students, while they were used in private schools. The aggregate mean $(\bar{x} \bar{x})=2.48$ which is less than the criterion mean $=2.50$ implies that teachers of oral English rarely possess the skills to use the ICT facilities to teach oral English in the public and private secondary schools in ONELGA..

Research Question 3: What are the problems encountered by students in public and private secondary schools regarding their learning of oral English in ONELGA? 
Table 3. Problem encountered by students in public and private secondary schools regarding their learning of oral English in ONELGA

\begin{tabular}{|c|c|c|c|c|c|c|}
\hline \multirow[t]{2}{*}{$\mathrm{S} / \mathrm{N}$} & \multirow[t]{2}{*}{ Items } & \multicolumn{2}{|l|}{ Schools } & \multirow{2}{*}{$\begin{array}{l}\text { Mean set } \\
\mathrm{xx} / 2\end{array}$} & \multirow[t]{2}{*}{ SD } & \multirow[t]{2}{*}{ Decision } \\
\hline & & $\begin{array}{l}\text { Public } \bar{x} \bar{x} \\
(\mathrm{~N}=90)\end{array}$ & $\begin{array}{l}\text { Private }^{\bar{x} \bar{x}} \\
(\mathrm{~N}=60)\end{array}$ & & & \\
\hline 11. & $\begin{array}{l}\text { All students of oral English have } \\
\text { problems of pronunciation. }\end{array}$ & 3.98 & 3.60 & 3.83 & 1.38 & Accepted \\
\hline 12. & $\begin{array}{l}\text { Students of oral English have problem } \\
\text { distinguishing long sound from short. }\end{array}$ & 3.94 & 3.83 & 3.90 & 1.25 & Accepted \\
\hline 13. & $\begin{array}{l}\text { All students of oral English have } \\
\text { problems } f \text { articulation of sound. }\end{array}$ & 3.57 & 3.42 & 3.51 & 1.38 & Accepted \\
\hline 14. & $\begin{array}{l}\text { All students of oral English can identify } \\
\text { the place and manners of articulation. }\end{array}$ & 2.84 & 3.17 & 2.97 & 1.44 & Accepted \\
\hline 15. & $\begin{array}{l}\text { All students are not familiar with ICT } \\
\text { facilities as related to the learning of } \\
\text { phonetics. }\end{array}$ & 2.82 & 2.73 & 2.77 & 1.43 & Accepted \\
\hline 16. & $\begin{array}{l}\text { All students are familiar with ICT } \\
\text { facilities as related to the learning of } \\
\text { phonetics. }\end{array}$ & 3.33 & 3.15 & 3.26 & 1.58 & Accepted \\
\hline \multirow[t]{2}{*}{17.} & $\begin{array}{l}\text { The use of ICT does not stimulate the } \\
\text { interest of the students in the learning of } \\
\text { phonetics. }\end{array}$ & 3.11 & 2.38 & 2.82 & 1.56 & Accepted \\
\hline & Aggregate Mean & & & 3.29 & 1.43 & \\
\hline
\end{tabular}

Table three: reveals that items 1-17 state that all students of oral English have problem $\mathrm{f}$ pronunciation, students of oral English have problem distinguishing long sound from short, all students of oral English have problem of articulation of sound, all students of oral English can identify the place and manners of articulation, all students are not familiar with ICT facilities as related to the learning of phonetics, all students are familiar with ICT facilities as related to the learning of phonetics and the use of ICT do not stimulates the interest of the students in the learning of phonetics were accepted. The aggregate mean $=3.29$ which is greater than the criterion mean, implies that most of these are problems encountered by students in public and private secondary schools regarding their learning of oral English in ONELGA. 
Research Question 4: To what extent are ICT facilities available in rural and urban areas of Rivers State?

Table 4. Observation Checklist on Availability of ICT Facilities in Rural and Urban Secondary Schools in ONELGA.

\begin{tabular}{|c|c|c|c|c|c|c|c|c|c|}
\hline & & \multicolumn{2}{|c|}{ Available } & \multicolumn{2}{|c|}{ Not Available } & \multicolumn{2}{|c|}{ Available } & \multicolumn{2}{|c|}{ Not Available } \\
\hline & & $\mathbf{F}$ & $\%$ & $\mathbf{F}$ & $\%$ & $\mathbf{F}$ & $\%$ & $\mathbf{F}$ & $\%$ \\
\hline 1. & Computer & 40 & $26.7 \%$ & 20 & $13.3 \%$ & 20 & $13.3 \%$ & 70 & $46.7 \%$ \\
\hline 2. & Television & 45 & $30.0 \%$ & 15 & $10.0 \%$ & 10 & $6.7 \%$ & 80 & $53.3 \%$ \\
\hline 3. & Voice recorded & 32 & $21.3 \%$ & 28 & $18.7 \%$ & 8 & $5.3 \%$ & 82 & $54.7 \%$ \\
\hline 4. & Smart board & 25 & $16.7 \%$ & 35 & $23.3 \%$ & 3 & $2.0 \%$ & 87 & $58.0 \%$ \\
\hline 5. & Laptops & 55 & $36.7 \%$ & 5 & $3.3 \%$ & 23 & $15.3 \%$ & 67 & $44.7 \%$ \\
\hline 6. & Android phones & 50 & $33.3 \%$ & 10 & $6.7 \%$ & 35 & $23.3 \%$ & 55 & $36.7 \%$ \\
\hline 7. & CD-ROMS & 42 & $28.0 \%$ & 18 & $12.0 \%$ & 10 & $6.7 \%$ & 80 & $53.3 \%$ \\
\hline 8. & $\begin{array}{l}\text { Interactive } \\
\text { whiteboard }\end{array}$ & 22 & $14.7 \%$ & 38 & $25.3 \%$ & 2 & $1.3 \%$ & 88 & $58.7 \%$ \\
\hline 9. & Digital cameras & 35 & $23.3 \%$ & 25 & $16.7 \%$ & 11 & $7.3 \%$ & 79 & $52.7 \%$ \\
\hline 10. & Programmable toys & 15 & $10.0 \%$ & 45 & $30.0 \%$ & 0 & $0.0 \%$ & 90 & $60.0 \%$ \\
\hline \multirow[t]{2}{*}{11.} & Projectors & 44 & $29.3 \%$ & 16 & $10.7 \%$ & 5 & $3.3 \%$ & 85 & $56.7 \%$ \\
\hline & Average (\%) & 405 & $24.5 \%$ & 255 & $15.5 \%$ & 127 & $7.7 \%$ & 863 & $52.3 \%$ \\
\hline
\end{tabular}

Table four: shows that $33.3 \%$ of the respondents from urban schools had access to android phones, while $6.7 \%$ did not. In the rural schools $23.3 \%$ had access to android phones, while $36.7 \%$ did not. The percentages of the availability of various ICT facilities on the checklist in the assessed urban schools ranged between $10 \%$ and $33.3 \%$ while the percentages of the unavailability of the ICT facilities ranged between $6.7 \%$ and $30.0 \%$. In the rural schools, it ranged between $0 \%$ and $60 \%$. However, on average, $24.5 \%$ from urban schools had access to ICT facilities listed on the checklist while $15.5 \%$ did not. In the rural schools, $7.7 \%$ had access to ICT facilities listed on the checklist while $52.3 \%$ did not have the ICT facilities. This means that the availability of ICT facilities in rural secondary schools in ONELGA was low at the time of conducting this research. 


\section{Test of Hypotheses}

H01: There is no significant difference in the availabilities of ICT facilities for teaching oral English in public and private secondary schools in ONELGA.

Table 5a. Contingency table showing availabilities of ICT facilities for teaching oral English in public and private secondary schools

\begin{tabular}{|c|c|c|c|c|c|c|c|}
\hline \multirow[t]{4}{*}{$\mathrm{S} / \mathrm{N}$} & \multirow[t]{4}{*}{ ITEMS } & & \multicolumn{4}{|c|}{ SCHOOLS } & \multirow[t]{4}{*}{ Total } \\
\hline & & & \multicolumn{2}{|c|}{ PUBLIC (90) } & \multicolumn{2}{|c|}{ PRIVATE (60) } & \\
\hline & & & Available & & Available & & \\
\hline & & & & Available & & Available & \\
\hline \multirow[t]{2}{*}{1.} & Computer & Count & 20 & 70 & 50 & 10 & 150 \\
\hline & & $\begin{array}{l}\text { Expected } \\
\text { Count }\end{array}$ & 11.2 & 78.8 & 37.1 & 22.9 & 150.0 \\
\hline \multirow[t]{2}{*}{2.} & Television & Count & 3 & 87 & 40 & 20 & 150 \\
\hline & & $\begin{array}{l}\text { Expected } \\
\text { Count }\end{array}$ & 11.2 & 78.8 & 37.1 & 22.9 & 150.0 \\
\hline \multirow[t]{2}{*}{3.} & Voice recorded & Count & 2 & 88 & 30 & 30 & 150 \\
\hline & & $\begin{array}{l}\text { Expected } \\
\text { Count }\end{array}$ & 11.2 & 78.8 & 37.1 & 22.9 & 150.0 \\
\hline \multirow[t]{2}{*}{4.} & Smart board & Count & 10 & 80 & 40 & 20 & 150 \\
\hline & & $\begin{array}{l}\text { Expected } \\
\text { Count }\end{array}$ & 11.2 & 78.8 & 37.1 & 22.9 & 150.0 \\
\hline \multirow[t]{2}{*}{5.} & Laptops & Count & 23 & 67 & 45 & 15 & 150 \\
\hline & & $\begin{array}{l}\text { Expected } \\
\text { Count }\end{array}$ & 11.2 & 78.8 & 37.1 & 22.9 & 150.0 \\
\hline \multirow[t]{2}{*}{6.} & Android phones & Count & 35 & 55 & 50 & 10 & 150 \\
\hline & & $\begin{array}{l}\text { Expected } \\
\text { Count }\end{array}$ & 11.2 & 78.8 & 37.1 & 22.9 & 150.0 \\
\hline \multirow[t]{2}{*}{7.} & CD-ROMS & Count & 19 & 71 & 45 & 15 & 150 \\
\hline & & $\begin{array}{l}\text { Expected } \\
\text { Count }\end{array}$ & 11.2 & 78.8 & 37.1 & 22.9 & 150.0 \\
\hline \multirow[t]{2}{*}{8.} & Interactive whiteboar & Count & 2 & 88 & 32 & 28 & 150 \\
\hline & & $\begin{array}{l}\text { Expected } \\
\text { Count }\end{array}$ & 11.2 & 78.8 & 37.1 & 22.9 & 150.0 \\
\hline \multirow[t]{2}{*}{9.} & Digital cameras & Count & 5 & 85 & 21 & 39 & 150 \\
\hline & & $\begin{array}{l}\text { Expected } \\
\text { Count }\end{array}$ & 11.2 & 78.8 & 37.1 & 22.9 & 150.0 \\
\hline \multirow[t]{2}{*}{10.} & Programmable toys & Count & 0 & 90 & 15 & 45 & 150 \\
\hline & & $\begin{array}{l}\text { Expected } \\
\text { Count }\end{array}$ & 11.2 & 78.8 & 37.1 & 22.9 & 150.0 \\
\hline \multirow[t]{4}{*}{11.} & Projectors & Count & 4 & 86 & 40 & 20 & 150 \\
\hline & & $\begin{array}{l}\text { Expected } \\
\text { Count }\end{array}$ & 11.2 & 78.8 & 37.1 & 22.9 & 150.0 \\
\hline & Total & Count & 123 & 867 & 408 & 252 & 1650 \\
\hline & & $\begin{array}{l}\text { Expected } \\
\text { Count }\end{array}$ & 123.0 & 867.0 & 408.0 & 252.0 & 1650.0 \\
\hline
\end{tabular}


The survey of chi-square is presented in the table that follows;

$x^{2} x^{2}$

Table 5b. $\boldsymbol{x}^{2}$ analysis of differences between public and private secondary schools in ONELGA

\begin{tabular}{llllllll}
\hline VARIABLES & \multicolumn{1}{c}{$\mathrm{N}$} & $\mathrm{Df}$ & $x x_{2_{2}}$ & $\begin{array}{l}\text { Sig. } \\
(2 \text {-tailed })\end{array}$ & $\begin{array}{l}\text { Level } \\
\text { Sig. }\end{array}$ & of $x x_{2}$ crit. & Decision \\
\hline $\begin{array}{l}\text { PUBLIC } \\
\text { SCHOOLS }\end{array}$ & SECONDARY 150 & 30 & 224.795 & 0.00 & 0.05 & 43.77 & $\begin{array}{l}\text { H01 } \\
\text { Rejected }\end{array}$ \\
\hline PRIVATE & SECONDARY & & & & & & \\
SCHOOLS & & & & & & & \\
\hline
\end{tabular}

Table 5.b reveals that the $x_{2}$ cal is 224.795 with df $=30$ and $\mathrm{p}<0.05$. The obtained $x_{2}$ cal value of 224.795 is greater than ${ }^{x x_{2}}$ crit. $=43.77$, therefore the null hypothesis that there is no significant difference between public and private secondary schools in ONELGA, is rejected. This indicates that there is a significant difference between public and private secondary schools in ONELGA.

H02: There is no significant difference among teachers in public and private secondary schools regarding the skills they possess in the use of ICT facilities to teach oral English.

Table 6. z-test analysis of differences between public and private secondary schools regarding the skills they possess in the use of ICT facilities to teach oral English

\begin{tabular}{lllllllllll}
\hline & GROUPS & $\mathrm{N}$ & Mean & $\begin{array}{l}\text { Std. } \\
\text { Deviation }\end{array}$ & Df & $\mathrm{t}$-cal & t-crit & $\begin{array}{l}\text { Sig. } \\
\text { (2-tailed) }\end{array}$ & $\begin{array}{l}\text { Level } \\
\text { Sig. }\end{array}$ & ofDecision \\
\hline SKILLS & PUBLIC & 90 & 2.07 & 1.22 & 2 & -4.483 & 1.96 & 0.000 & 0.05 & H02accepted \\
\cline { 2 - 10 } & PRIVATE & 60 & 3.09 & 1.56 & 148 & & & & & \\
\hline
\end{tabular}

Table 6: reveals that public school students had a mean score of 2.07, while the private school students had 3.09. When subjected to z-test statistics, a calculated $t$-value of -4.483 was obtained. The calculated $t$-value of -4.483 was significant at a level of 0.00 which is less than the chosen 0.05 level of significance, hence, the null hypotheses was accepted. This indicates that there is a significant difference in the mean rating of public and private secondary schools regarding the skills they possess in the use of ICT facilities to teach oral English in ONELGA.

H03: There is no significant difference between the students in public and private secondary schools regarding the problems they encountered in learning oral English.

Table 7. z-test analysis of differences between the students in public and private secondary schools regarding the problems they encountered in learning oral English

\begin{tabular}{|c|c|c|c|c|c|c|c|c|c|c|}
\hline & GROUPS & $\mathrm{N}$ & Mean & $\begin{array}{l}\text { Std. } \\
\text { Deviation }\end{array}$ & Df & $\mathrm{t}$-cal & t-crit & $\begin{array}{l}\text { Sig. } \\
\text { (2-tailed) }\end{array}$ & $\begin{array}{l}\text { Level } \\
\text { Sig. }\end{array}$ & ofDecision \\
\hline \multirow[t]{3}{*}{ PROBLEMS } & PUBLIC & 90 & 2.07 & 1.22 & 2 & 0.752 & 1.96 & 0.453 & 0.05 & $\mathrm{H} 03$ \\
\hline & & & & & & & & & & Accepted \\
\hline & PRIVATE & 60 & 3.09 & 1.56 & 148 & & & & & \\
\hline
\end{tabular}

The results in Table: indicated that when the mean difference was subjected to an independent t-test, a calculated $\mathrm{t}$-value of 0.752 at degree of freedom of 148 was obtained. This calculated $t$-value of 0.752 was not significant at 0.453 probability level, which is greater than 0.05 , the chosen level of probability (tcal $=0.752, \mathrm{p}<0.05$ ). Hypothesis three was accepted. Hence a significant difference does not existed in the mean scores between the students in public and private secondary schools regarding the problems they encountered in learning oral English.

H04: There is no significant difference in the availability of ICT facilities in both rural and urban area in ONELGA. 
Table 8a. Contingency table showing availability of ICT facilities in both rural and urban areas in ONELGA

\begin{tabular}{|c|c|c|c|c|c|c|c|}
\hline \multirow[t]{4}{*}{$\mathrm{S} / \mathrm{N}$} & \multirow[t]{4}{*}{ ITEMS } & & \multicolumn{4}{|c|}{ LOCATION OF SCHOOLS } & \multirow[t]{4}{*}{ Total } \\
\hline & & & \multicolumn{2}{|c|}{$\overline{\text { URBAN (60) }}$} & \multicolumn{2}{|c|}{ RURAL (60) } & \\
\hline & & & Available & Not & Available & Not & \\
\hline & & & & Available & & Available & \\
\hline \multirow[t]{2}{*}{1.} & Computer & Count & 40 & 20 & 20 & 70 & 150 \\
\hline & & $\begin{array}{l}\text { Expected } \\
\text { Count }\end{array}$ & 36.8 & 23.2 & 11.5 & 78.5 & 150.0 \\
\hline \multirow[t]{2}{*}{2.} & Television & Count & 45 & 15 & 10 & 80 & 150 \\
\hline & & $\begin{array}{l}\text { Expected } \\
\text { Count }\end{array}$ & 36.8 & 23.2 & 11.5 & 78.5 & 150.0 \\
\hline \multirow[t]{2}{*}{3.} & Voice recorded & Count & 32 & 28 & 8 & 82 & 150 \\
\hline & & $\begin{array}{l}\text { Expected } \\
\text { Count }\end{array}$ & 36.8 & 23.2 & 11.5 & 78.5 & 150.0 \\
\hline \multirow[t]{2}{*}{4.} & Smart board & Count & 25 & 35 & 3 & 87 & 150 \\
\hline & & $\begin{array}{l}\text { Expected } \\
\text { Count }\end{array}$ & 36.8 & 23.2 & 11.5 & 78.5 & 150.0 \\
\hline \multirow[t]{2}{*}{5.} & Laptops & Count & 55 & 5 & 23 & 67 & 150 \\
\hline & & $\begin{array}{l}\text { Expected } \\
\text { Count }\end{array}$ & 36.8 & 23.2 & 11.5 & 78.5 & 150.0 \\
\hline \multirow[t]{2}{*}{6.} & Android phones & Count & 50 & 10 & 35 & 55 & 150 \\
\hline & & $\begin{array}{l}\text { Expected } \\
\text { Count }\end{array}$ & 36.8 & 23.2 & 11.5 & 78.5 & 150.0 \\
\hline \multirow[t]{2}{*}{7.} & CD-ROMS & Count & 42 & 18 & 10 & 80 & 150 \\
\hline & & $\begin{array}{l}\text { Expected } \\
\text { Count }\end{array}$ & 36.8 & 23.2 & 11.5 & 78.5 & 150.0 \\
\hline \multirow[t]{2}{*}{8.} & Interactive whiteboar & dCount & 22 & 38 & 2 & 88 & 150 \\
\hline & & $\begin{array}{l}\text { Expected } \\
\text { Count }\end{array}$ & 36.8 & 23.2 & 11.5 & 78.5 & 150.0 \\
\hline \multirow[t]{2}{*}{9.} & Digital cameras & Count & 35 & 25 & 11 & 79 & 150 \\
\hline & & $\begin{array}{l}\text { Expected } \\
\text { Count }\end{array}$ & 36.8 & 23.2 & 11.5 & 78.5 & 150.0 \\
\hline \multirow[t]{2}{*}{10.} & Programmable toys & Count & 15 & 45 & 0 & 90 & 150 \\
\hline & & $\begin{array}{l}\text { Expected } \\
\text { Count }\end{array}$ & 36.8 & 23.2 & 11.5 & 78.5 & 150.0 \\
\hline \multirow[t]{4}{*}{11.} & Projectors & Count & 44 & 16 & 5 & 85 & 150 \\
\hline & & $\begin{array}{l}\text { Expected } \\
\text { Count }\end{array}$ & 36.8 & 23.2 & 11.5 & 78.5 & 150.0 \\
\hline & Total & Count & 405 & 255 & 127 & 863 & 1650 \\
\hline & & $\begin{array}{l}\text { Expected } \\
\text { Count }\end{array}$ & 405.0 & 255.0 & 127.0 & 863.0 & 1650.0 \\
\hline
\end{tabular}

The survey of chi-square is presented in he table that follows

Table 8b. $\boldsymbol{x}^{\mathbf{2}} \boldsymbol{x}^{\mathbf{2}}$ analysis of differences between availability of ICT facilities in both rural and urban areas in ONELGA

\begin{tabular}{llllllll}
\hline VARIABLES & $\mathrm{N}$ & $\mathrm{Df}$ & $x x_{2}$ cal & $\begin{array}{l}\text { Sig. } \\
(2 \text {-tailed })\end{array}$ & Level of Sig. & $x x_{2}$ crit. & Decision \\
\hline URBAN & 60 & 30 & 217.330 & 0.00 & 0.05 & 43.77 & H01 Rejected \\
\hline RURAL & 90 & & & & & & \\
\hline
\end{tabular}


Table 8: reveals that the $x_{2}$ cal is 217.330 with $\mathrm{df}=30$ and $\mathrm{p}<0.05$. The obtained $x_{2}$ cal value of 217.330 is greater than ${ }^{x x_{2}}$ crit. $=43.77$, therefore the null hypothesis that there is no significant difference in the availability of ICT facilities in both rural and urban areas in ONELGA, is rejected. This indicates that there is a significant difference between the availability of ICT facilities in both rural and urban areas in ONELGA.

\section{Discussion of Results}

From this survey, it is apparent that the availability of ICT for learning oral English in ONELGA secondary schools is very low at the time of this study. Most students are not familiar with ICT not to talk of using it to learn phonetics in their classes. The research has shown here that difference is observed in the availability of ICT facilities in the rural and urban areas. That is to say the students in the urban area are more familiar with ICT facilities than their mates in the rural area. This study is akin to the findings of Nwagbogwu (2008), which reported that ICTs were not used to learn the English language as a Second Language in the Nigeria Universities. This same related the study of Osagie (2008) suggesting that ICT was not used for learning purposes rather for social networks and playing games among ESL learners in the Edo state. This study also discovered that a high percentage of teachers rarely possessed the skills to use ICT facilities to teach oral English in secondary schools. This is related to the findings of Andrews (2003), which also reveal that. This is to say that it is very important that teachers should be aware of their roles in the classroom for a positive change in learning. The finding is in line with Lawal's report (2001) which stated that. Catford (1994) clearly suggested that; the trained teachers of phonetics should have good understanding of sound in relation to spelling, spoken language as well as the teaching and learning of sound production.

From the observational checklist, good numbers of students have affirmed that they were not applying ICT facilities to learn spelling and oral English. The study further revealed that all students of oral English had the same problem of pronunciation, problem of distinguishing long sound from short, problem of articulation of sound, problem of identifying the place and manners of articulation etc. The aggregate mean $=3.29$ that is higher than the criterion mean implies that, these are the problems countered by the learners of public and private secondary schools in the learning of oral English in ONELGA. This is related to the findings of Gujarat (2001) which revealed that pronunciation and spoken English are very challenging activities. The findings of Gujarat is a bit different from the findings of Burnett, Merchant and Myers (2007) who found out that there will be paradigm shift in the learning of English language as a subject, by embracing technology as a means of learning language. The study concludes with the note that it is essential that encouragement is given to teachers of the English language to recognize the important of ICT in the teaching of English phonetics in the Nigeria secondary schools

\section{Summary of the Results}

The results of the data analyzed are summarized as follows

- There is a significant difference in the availability of ICT facilities in public and private secondary schools in ONELGA. This simply implies that there are more ICT facilities in private schools than in public schools at the time of this study.

- There is no significant difference in the mean rating of public and private secondary schools teachers regarding the skills they possess in the use of ICT facilities to teach oral English in ONELGA secondary schools.

- A significant difference does not exist in the mean scores between the students in public and private secondary schools regarding the problems they encountered in learning oral English. There is a significant difference in the availability of ICT facilities in both rural and urban area of ONELGA. This means that the students in the urban area are more exposed to the ICT facilities than those in the rural area.

- There is a significant difference in the availability of ICT facilities in both rural and urban areas of ONELGA. This means that the students in the urban rea are more exposed to the ICT facilities than those in the rural area.

\section{Conclusion}

This survey is centered on the introduction of ICT into the learning of phonetics among senior secondary learners of oral English in ONELGA. From the investigations, it was discovered that the availability of ICT at the time of this study is low. The research work has also discovered that the teachers of oral English rarely used the ICT facilities for the teaching and learning of oral English in secondary schools. With the use of ICT as teaching aids, a competent speaker of English language will be since it can help greatly in the area of pronunciation and spelling even among the teachers. That is to say here that the introduction of ICT and the ill help in the learning of phonetics. 
With the feedback from both public and private secondary schools, it is obvious that the use of ICT for the learning of oral English has not actually gained round in ONELGA. Hence action needs to be taken to fully introduce the use of ITC in the classroom for both students and teachers to facilitate he learning of oral English.

The following recommendations were made from the findings of this study.

- Teachers of oral English and students should adopt ICT as teaching aids for the teaching and learning of oral English. In doing that, it will help to resolve pronunciation and spelling errors.

- The federal Government should provide ICTs in schools in order to implement the National Policy on Education (2014) edition that says that there is immediate need to integrate ICT into teaching and learning in secondary schools.

- The Government and other educators should make effort if this ICT are provided to supervise them in other to make sure that they are put into use.

- Schools should employ teachers that have the knowledge of phonetics and ICT in order to the learners of oral English.

\section{Contribution to Knowledge}

The finding of this research work has some contributions to knowledge.

- Learning phonetics is more effective if ICT is used as an instructional material. From the result of this research work, the use of ICT improves students learning of phonetics than is the case with the traditional approach.

- $\quad$ The research presents as part of the contribution to knowledge that most teachers in the Senior Secondary Schools cannot handle and use many of these ICT's. Mostly in the literature, many scholars complain about the lack of ICT's material but none in our knowledge has expressed the lack of technical know-how of the teachers who need these ICTs.

\section{References}

Burnett, M \& Mayers, C. (2007). Is there a space for critical literacy in the cotest of social media? Retrieved from www.acadamia.edu/.../. On the 16 of September, 2015.

Grabe, M. \& Grabe, C. (2005). Integrating technology for meaningful learning. USA: Houghton Mifflin.

Graham, D. (2011). Innovative teaching methodology: Application of computer. Retrieved from, www.academypublication.com/...08.pdf. On the 12 Octomber 2015.

Herb T. (2000). Computer mediated communication for learning and teaching: An analysis. Retrieved on the $3^{\text {rd }}$ of October, 2015: from http://www1.aucegypt.edu/faculty/thompson/herbtea/articles/iadat_15.pdf

Hiltz, D. (1988). Teaching philosophy. Retrieved from www. Jaist.ac.jp/ johnb/pdfs/tpsv3.pdf. on 12 November, 2015.

Hoven, D. (1999). Language pedagogy and computer - enhanced language learning (CELL). Retrieved from web.stanford.edu/ efs.../callcc-intro.pdf 25 August, 2015.

Krashen, S. G. (1982). The principles and practice in second language acquisition. Pergamon: Turkey.

Manyard, J. (2009). How computer technology can promote learners autonomy. Retrieved on the 05 October, 2015 from LASIG: Learners autonomy. Special interestgroup website: http//www.Learnerauthonomy. or/ mynardhanout.pdf

Osagie, R. (2008). The use of ICT in language learning. M A Thesis: University of Benin.

Yunus, M (2007). Malaysian ESL teachers' use of ICT Classrooms. Eurocall, 9(1), 79-95. https://doi.org/10.1017/S0958344007000614

Zhoa. (2004). Recent development in technology and language learning. CALICO Journal, 21(1), retrieved on the 05th September, 2015 from website https://calico.org/html/article 279.pdf. 